\title{
The Evolution of Precipitates, in particular Cruciform and Cuboid particles, during Simulated Direct Charging of Thin Slab Cast Vanadium Microalloyed Steels.
}

\author{
T.N.Baker ${ }^{*}$, Y.Li $^{*}$, J.A. Wilson ${ }^{\ddagger}$, A.J.Craven ${ }^{\ddagger}$ and D.N.Crowther ${ }^{\dagger}$ \\ *Metallurgy and Engineering Materials Group, Department of Mechanical Engineering, \\ University of Strathclyde, Glasgow G1 1XJ \\ \$Department of Physics and Astronomy, University of Glasgow G12 8QQ \\ $\dagger$ Corus Group, Swinden Technology Centre, Rotherham S60 3AR
}

\section{ABSTRACT}

A study has been undertaken of four vanadium based steels which have been processed by a simulated direct charging route using processing parameters typical of thin slab casting, where the cast product has a thickness of 50 to $80 \mathrm{~mm}$ ( in this study $50 \mathrm{~mm}$ ) and is fed directly to a furnace to equalise the microstructure prior to rolling. In the direct charging process, cooling rates are faster, equalisation times shorter and the amount of deformation introduced during rolling less than in conventional practice. Samples in this study were quenched after casting, after equalisation, after $4^{\text {th }}$ rolling pass and after coiling, to follow the evolution of microstructure. The mechanical and toughness properties and the microstructural features might be expected to differ from equivalent steels, which have undergone conventional processing. The four low carbon steels $(\sim 0.06 \mathrm{wt} \%)$ which were studied contained $0.1 \mathrm{wt} \% \mathrm{~V}(\mathrm{~V}-\mathrm{N}), 0.1 \mathrm{wt} \% \mathrm{~V}$ and $0.010 \mathrm{wt} \% \mathrm{Ti}(\mathrm{V}-\mathrm{Ti}), 0.1 \mathrm{wt} \% \mathrm{~V}$ and $0.03 \mathrm{wt} \% \mathrm{Nb}(\mathrm{V}-$ $\mathrm{Nb}$ ), and $0.1 \mathrm{wt} \% \mathrm{~V}, 0.03 \mathrm{wt} \% \mathrm{Nb}$ and $0.007 \mathrm{wt} \% \mathrm{Ti}(\mathrm{V}-\mathrm{Nb}-\mathrm{Ti})$. Steels $\mathrm{V}-\mathrm{N}$ and V-Ti contained around $0.02 \mathrm{wt} \% \mathrm{~N}$, while the other two contained about $0.01 \mathrm{wt} \% \mathrm{~N}$. The as-cast steels were heated at three equalising temperatures of $1050^{\circ} \mathrm{C}, 1100^{\circ} \mathrm{C}$ or $1200^{\circ} \mathrm{C}$ and held for $30-60$ minutes prior to rolling. Optical microscopy and analytical electron microscopy, including parallel electron energy loss spectroscopy (PEELS), were used to characterise the 
precipitates. In the as-cast condition, dendrites and plates were found. Cuboid particles were seen at this stage in Steel V-Ti, but they appeared only in the other steels after equalization. In addition, in the final product of all the steels, fine particles were seen, but it was only in the two titanium steels that cruciform precipitates were present. PEELS analysis showed that the dendrites, plates, cuboids, cruciforms and fine precipitates were essentially nitrides. The two Ti steels had better toughness than the other steels but inferior lower yield stress values. This was thought to be, in part, due to the formation of cruciform precipitates in austenite, thereby removing nitrogen and the microalloying elements which would have been expected to precipitate in ferrite as dispersion hardening particles.

Dr Li is now with Vanitec, Winterton House, High Street, Westerham, Kent,TN16 1AQ

\section{INTRODUCTION}

Microstructural characterisation of as-cast microalloyed steels has received far less attention than that of the final product ${ }^{1}$. Post-cast processing of conventional thick cast slabs of structural steels of $\sim 200 \mathrm{~mm}$ thickness is usually considered to remove most of the features of the as-cast microstructure. However, in the thin slab casting and direct rolling process (TSDR), the as-cast product which has a thickness of $50-80 \mathrm{~mm}$, the cooling rates are faster, the equalisation times shorter and the amount of deformation introduced during rolling less than in conventional practice. Some aspects of the microstructural features from the as-cast condition are therefore more likely to be inherited in the later stages of processing or even in the final product ${ }^{2-7}$. The faster cooling rates may result in an austenite phase which is more supersaturated with alloying elements, while the final product may have mechanical and toughness properties which are different from steels which have undergone conventional processing. A more detailed investigation of the evolution of the microstructure, and particularly the precipitates present during the TSDR process, is therefore merited to 
understand the relationship between processing parameters, chemical composition of the steels and resultant properties.

Many of the papers in the literature which discuss the microstructure of as-cast microalloyed steels consider steels with carbon levels $>0.1 \mathrm{wt} \%$, and report large precipitates in the form of plates, dendrites or a eutectic phase ${ }^{8-12}$. These are less in evidence when the level of carbon is $<0.06 \mathrm{wt} \%,{ }^{13,14}$. The observation of cruciform or star-like particles, with up to six arms, sometimes described as legs, growing from a core, is a feature of microalloyed steels having additions of titanium, usually with vanadium and or niobium ${ }^{1,9,15,16}$. An example is shown in Fig. 1a. In TDSR processed steels such cruciforms are not found in the as-cast specimens but are observed after an equalisation treatment. They then remain throughout the processing and are observed in the final product, but often appear as though broken-up by the rolling process ${ }^{17}$. In recent work on laboratory simulated TSDR cast V-Ti steels, these particles were frequently observed to be associated with a grain or phase boundary. The cruciforms are sometimes too widely spaced to have a major influence on the grain boundary pinning of the austenite grains. However, their presence removes alloying elements (e.g. vanadium, niobium and nitrogen) which would normally be expected to contribute to dispersion hardening by precipitating in ferrite as a fine particle dispersion circa $2-15 \mathrm{~nm}$ in size. Zhou and Priestner ${ }^{18}$ observed cruciforms in Nb-Ti microalloyed steels. These had an average $\mathrm{Ti} /(\mathrm{Ti}+\mathrm{Nb})$ atomic ratio $<0.5$, but the individual values observed varied over a significant range. Several reports in the literature consider cruciforms to consist of a TiN particle having a cubic morphology, which has acted as a heterogeneous nucleant for arms ${ }^{1,9,13,15,16}$. In the case of Ti-Nb steels reported by He and Baker ${ }^{16}$, the cruciforms were confined to one steel of the four studied, which contained $0.008 \mathrm{wt} \% \mathrm{Ti}$. However, the chemical composition of the cruciforms has not been considered in detail previously due to the difficulty of obtaining reliable quantitative light element data.

In Ti-Nb steels, the composition of the core and arms were similar, both being essentially 
$(\mathrm{Ti}, \mathrm{Nb}) \mathrm{N}^{19}$, with a $\mathrm{Ti} /(\mathrm{Ti}+\mathrm{Nb})$ atomic ratio in the range 0.6 to 0.85 . Another complex particle was reported in these steels ${ }^{16,19}$. This had a core with caps heterogeneously nucleated on one or more of the faces, as in Fig $1 \mathrm{~b},{ }^{1,13,15,16}$. Usually the core, which had a composition based on Ti $(\mathrm{CN})$, had a cubic morphology, with up to six caps growing in $<100>$ directions. The composition of the caps varied from ( $\mathrm{Nb}, \mathrm{Ti}) \mathrm{CN}$ to $\mathrm{NbC}$ and then to $\mathrm{Nb}(\mathrm{CN})$, depending on the steel composition ${ }^{19}$.

When the carbon content is $>0.065 \mathrm{wt} \%$, it is known that the $\mathrm{Ti}(\mathrm{CN})$ particles precipitate either in the liquid or in the interdendritic $\delta$ ferrite phases ${ }^{7}$. However, when the carbon content is $<0.065 \mathrm{wt} \%$, the peritectic reaction is avoided and the liquid solidifies directly to $\delta$ ferrite. In this situation, TiN often nucleates heterogeneously, sometimes on sulphides such as $\mathrm{CaS}, \mathrm{CuS}$, or MnS, or oxides, such as $\mathrm{Al}_{2} \mathrm{O}_{3}{ }^{1,20-22}$.

By comparison, it appears that the cruciform particles precipitate at lower temperatures in austenite. An addition of titanium does not guarantee the presence of cruciform particles. For example, in a study on the microstructure of dual phase steels containing $0.085 \mathrm{wt} \% \mathrm{C}, 0.006$ $\mathrm{wt} \% \mathrm{~N}$ and $0.076 \mathrm{wt} \% \mathrm{Ti}$, TiN formed at high temperatures and acted as a heterogeneous nucleant for $\mathrm{Ti}_{4} \mathrm{C}_{2} \mathrm{~S}_{2}$ (hcp). This phase formed as a layer on the TiN (fcc) at temperatures $\sim 1260^{\circ} \mathrm{C}^{20}$.

Cruciform particles have also been identified in medium carbon steels, with $0.43 \mathrm{wt} \% \mathrm{C}$, $0.097 \mathrm{wt} \% \mathrm{~V}, 0.009 \mathrm{wt} \% \mathrm{Ti}$ and $0.011 \mathrm{wt} \% \mathrm{~N}$. This work also highlighted the stability of dendritic particles after $1 \mathrm{hr}$ at $1100^{\circ} \mathrm{C}^{10}$. In more recent studies, boundaries were observed which have other particles of different shapes and sizes, such as cuboids, aligned with the cruciforms ${ }^{17}$. Cuboids have been reported previously and are generally considered to develop during the post casting treatment ${ }^{9,10,14}$. This may be during air- cooling from casting, or reheating into the austenite phase, following cooling to room temperature in conventionally rolled steels. Such particles may have an important role in restricting austenite grain growth. 
Another morphological group of particles, which have a size of $2-15 \mathrm{~nm}$, are found in the final product. These fine particles, which are responsible for conferring dispersion strengthening, are usually considered to be carbonitrides or carbides which precipitate in the ferrite $^{13,23}$. In fact, there are only a few references in the literature to the characterisation of these particles due to their small size and the difficulty of accurate light element analysis ${ }^{24,25}$.

\section{Experimental Method}

The work was undertaken on four low carbon steels $(\sim 0.06 \mathrm{wt} \%)$ with $0.1 \mathrm{wt} \% \mathrm{~V}(\mathrm{~V}-\mathrm{N})$, $0.1 \mathrm{wt} \% \mathrm{~V}$ and $0.010 \mathrm{wt} \% \mathrm{Ti}(\mathrm{V}-\mathrm{Ti}), 0.1 \mathrm{wt} \% \mathrm{~V}$ and $0.03 \mathrm{wt} \% \mathrm{Nb}(\mathrm{V}-\mathrm{Nb})$, and $0.1 \mathrm{wt} \% \mathrm{~V}$, $0.03 \mathrm{wt} \% \mathrm{Nb}$ and $0.007 \mathrm{wt} \% \mathrm{Ti},(\mathrm{V}-\mathrm{Nb}-\mathrm{Ti})$. Steels $\mathrm{V}-\mathrm{N}$ and $\mathrm{V}-\mathrm{Ti}$ contained around $0.02 \mathrm{wt} \% \mathrm{~N}$, while the other two contained about $0.01 \mathrm{wt} \% \mathrm{~N}$. The chemical compositions of the steels are given in Table 1. The thin slab direct rolling processing was simulated at Corus Group, Swinden Technology Centre and a schematic diagram representing the process adopted in the present work is shown in Fig. 2. The steels were melted in air as $\sim 18 \mathrm{~kg}$ loads and cast into three moulds to produce $50 \mathrm{~mm}$ thick ingots. The typical cooling rate at the mid thickness position of the ingots was $3.5^{\circ} \mathrm{C} / \mathrm{s}$. The ingots were hot stripped from the mould and transferred directly to an equalising furnace set at temperatures of $1050^{\circ} \mathrm{C}, 1100^{\circ} \mathrm{C}$ or $1200^{\circ} \mathrm{C}$ and held for 30-60 minutes prior to rolling. After equalisation, the ingots were rolled on a laboratory reversing mill to $7 \mathrm{~mm}$ strips in 5 passes, which gave a total reduction of $86 \%$. A typical interpass time was $6 \mathrm{~s}$. After the 4th pass, the strip was held for approximately $25-40 \mathrm{~s}$ until a temperature of approximately $870^{\circ} \mathrm{C}$ was reached. Finish rolling temperatures varied from $880^{\circ} \mathrm{C}$ to $850^{\circ} \mathrm{C}$ and the total rolling times were in the range of $75-90 \mathrm{~s}$. After rolling, the strip was cooled under water sprays to simulate run-out table cooling. The end-cool temperature of the strip ranged from $504-700^{\circ} \mathrm{C}$. Following cooling, the strips were immediately put into a furnace set at $600^{\circ} \mathrm{C}$ and slow cooled (the average cooling rate between $600-400^{\circ} \mathrm{C}$ was $35^{\circ} \mathrm{C} / \mathrm{h}$ ) to simulate coiling. To follow the evolution of microstructure, samples were taken and immediately quenched at four stages in the process 
shown schematically in Fig. 2: after casting (A), after equalization (B), after the $4^{\text {th }}$ rolling pass (C) and after coiling (D). The temperatures for the steels at the different stages in the processing are given in Tables 2 and 3. In addition to examining these samples directly, some of the as-cast and quenched samples of Steel V-Ti were reheated and equalized at either $1050^{\circ} \mathrm{C}$ or $1100^{\circ} \mathrm{C}$ for 45 mins before again being quenched. This was to study the importance of the $\gamma \rightarrow \alpha$ phase transformation on the formation of cruciform precipitates. Samples were prepared for optical metallographic examination, and etched in $2 \%$ nital to reveal the microstructure. In the final strip, the ferrite grain size was measured using the linear intercept technique. Carbon extraction replicas were produced from the quarter thickness positions of the ingot, plate or strip and examined by analytical transmission electron microscopy using a Philips EM400T with an EDAX Phoenix energy dispersive x-ray (EDX) system, a Philips CM-20, and a VG HB5 scanning transmission electron microscope (STEM) with a Gatan 666 parallel electron energy loss spectrometer system (PEELS). A Fischione model 1020 plasma cleaning device was used for thinning the carbon extraction replicas used in the PEELS analysis ${ }^{26}$. This technique substantially lowered the level of the amorphous carbon contribution from the replica to the carbon edge in the PEELS spectrum, and allowed a distinction to be made between crystalline carbon combined in the transition metal carbide or carbonitride and amorphous carbon from the replica and other sources of contamination. The experimental details are given elsewhere ${ }^{17,25-30}$. Some thin foils were also prepared and examined, but this approach was discontinued at an early stage. As this project was concerned with variations in particle morphology, chemical composition and size throughout the processing route, it was considered that the removal of the iron background and the absence of strain contrast effects, both present in foils, was a major advantage when using replicas.

To assess the mechanical properties in the final strip ${ }^{27,28,30}$, duplicate, transverse full thickness tensile test pieces with a width of $12.5 \mathrm{~mm}$ and a gauge length of $50 \mathrm{~mm}$ were tested. Longitudinal $10 \mathrm{x} 5 \mathrm{~mm}$ 
Charpy test pieces ( $2 \mathrm{~mm}$ "V" notch) were tested over a range of temperatures to produce a complete impact transition curve. The solution temperatures of the carbonitrides and the weight percentage of the precipitates in the steels at various temperatures were calculated using the ChemSage thermodynamic software package, with a data base modified by A. J. Rose, Corus, Swinden Technology Centre, Rotherham ${ }^{31}$, so that our predictions matched those of Corus, with whom we were collaborating. ChemSage software was chosen following a survey undertaken by Corus. In their view, for microalloyed steels, ChemSage gave slightly better predictions than other commercial packages and it also included data on $\mathrm{Zr}$ compounds, which was not available with other software, at the time.

\subsection{Mechanical and Toughness Properties}

The mechanical and toughness properties are given in Table 3. By subtracting the ferrite lattice fraction stress and $\mathrm{C}+\mathrm{N}$ in solution $\left(\sigma_{\mathrm{o}}\right)$, together with the solid solution $\left(\sigma_{\mathrm{s}}\right)$ and grain size strengthening $\left(\sigma_{\mathrm{g}}\right)$ components from the measured lower yield strength $\left(\sigma_{\mathrm{y}}\right)$, using a modified version of the Hall-Petch equation, an estimate of the combined effect of the strengthening, conferred by dispersed incoherent particles and by dislocation strengthening, $\sigma_{\mathrm{d}}$, can be obtained.

$$
\begin{aligned}
& \sigma_{\mathrm{p}+} \sigma_{\mathrm{d}}=\sigma_{\mathrm{y}}-\left(\sigma_{\mathrm{o}}+\sigma_{\mathrm{s}}+\sigma_{\mathrm{g}}\right) \\
& \sigma_{\mathrm{o}}=45 \mathrm{MPa}{ }^{(32)} \\
& \sigma_{\mathrm{s}}=84(\mathrm{Si})+32(\mathrm{Mn})+38(\mathrm{Cu})+43(\mathrm{Ni})^{(33,34)} \\
& \sigma_{\mathrm{g}}=18.1 \mathrm{~d}^{-\frac{1}{2}}(35)
\end{aligned}
$$

The values of $\left(\sigma_{\mathrm{p}}+\sigma_{\mathrm{d}}\right)$ for the present steels are also given in Table 3 with the units in MPa. In this analysis, it was assumed that strengthening from dislocations and texture was low and similar for all the steels examined. The data show that the addition of titanium to vanadium or vanadium-niobium steels results in a decrease in the lower yield strength but a corresponding 
improvement in the Charpy toughness. The relationship between processing parameters, microstructure and properties is the subject of other papers ${ }^{28,36,37}$.

\subsection{Microstructure}

\section{Dendrites, Plates and Irregularly Shaped Particles}

After casting, only oxides (alumina) and sulphides, based on MnS, were observed in Steels $\mathrm{V}-\mathrm{N}$ and $\mathrm{V}-\mathrm{Nb}$, but TiN particles over $1 \mu \mathrm{m}$ in size were found in Steel V-Ti. The main precipitation in Steel V-Nb-Ti was in the form of large dendrites, Fig3. Their morphology was modified during subsequent processing, but they were not removed, Fig 4. Some large needles, $0.5 \mu \mathrm{m}$, in length were also found. Steel V-N contains $0.022 \mathrm{wt} \% \mathrm{~N}$, which means that there is an excess of vanadium in the steel. However, AlN was observed in Steel V-N as predicted by ChemSage calculations ${ }^{17,30}$. This AlN was often associated with MnS or MnS and $\mathrm{VN}^{28,33}$.

\section{Cruciforms}

For Steels V-N and V-Nb, no cruciform-shaped precipitates were observed at any stage in the processing. However, cruciforms, such as those seen in Figs 1a, 5, 6, were found in Steel V$\mathrm{Nb}$-Ti after all three equalisation temperatures. The V-Ti steel contained cruciform precipitates after equalisation at $1050^{\circ} \mathrm{C}$ and $1100^{\circ} \mathrm{C}$, but not after the $1200^{\circ} \mathrm{C}$ treatment, which is above the calculated cruciform solution temperature for the experimental particle compositions, which were obtained by $\mathrm{EDX}^{28}$. For the $1050^{\circ} \mathrm{C}$ equalisation temperature, the cruciform arm length was in the range $20-50 \mathrm{~nm}$. After equalisation at $1100^{\circ} \mathrm{C}$, the length of the cruciform arm had a wider range of $20-150 \mathrm{~nm}$. The cruciforms were normally observed at boundaries and often in the presence of cuboid particles in Steel V-Ti, but mainly in the 
matrix of Steel V-Nb-Ti. Once formed, they were carried through the processing route, but examples of break-up were observed, Fig 7.

When the as-cast and quenched samples from Steel V-Ti were re-heated, equalised for 45 mins at either $1050^{\circ} \mathrm{C}$ or $1100^{\circ} \mathrm{C}$ and re-quenched to ambient, cruciform precipitates were not observed. This is in contrast to the directly charged samples from the same steel, equalised at the same temperatures, after which cruciforms were observed.

In general for an equivalent treatment, the cruciforms seen in Steel V-Nb-Ti were smaller than in Steel V-Ti. For example, after equalisation at $1100^{\circ} \mathrm{C}$, in Steel V-Ti the cruciform arm lengths were 120-250nm, while in Steel V-Nb-Ti they were 36-160nm. However, in Steel V-Nb-Ti, after equalisation at $1100^{\circ} \mathrm{C}$ and rolling through the $4^{\text {th }}$ pass, the cruciforms were larger than those observed after the equalisation stage. The cruciform composition after the $4^{\text {th }}$ pass and in the final product was the same.

\section{Cuboidal particles in rows.}

For Steel V-N, no cuboids were observed after casting. However, cuboids were observed in Steel V-Ti, in the as-cast and quenched state, Fig 8, after equalisation at 1050 and $1100^{\circ} \mathrm{C}$, Fig 9, but not after equalisation at $1200^{\circ} \mathrm{C}$. It appears that the particles are associated with boundaries, as can be seen in Figs 5, 8 and 9, and some might even be an early stage in the formation of cruciforms. For the specimens studied after equalisation, the relevant boundaries will be those present in the austenite at the equalisation temperature, which is below the solution temperature of the particles ${ }^{17}$. Cuboidal particles were also observed after equalisation at 1050 and $1100^{\circ} \mathrm{C}$ in Steel V-Nb. They were also seen in Steel V-Nb-Ti after all three equalisation temperatures. In summary, for the Ti containing steels, the same specimens that contained cruciforms also showed cuboidal particles.

In Steel V-Ti, after equalisation at $1100^{\circ} \mathrm{C}$, these particles had less definite cuboidal shapes, as can be seen in Fig 5. The cuboids observed after $1050^{\circ} \mathrm{C}$ and $1100^{\circ} \mathrm{C}$ equalisation were in 
the range $10-50 \mathrm{~nm}$, which is larger than those observed after equalisation at $1200^{\circ} \mathrm{C}$, where they were in the range $7-20 \mathrm{~nm}$. The cuboids increased in size as the processing progressed. Thus after equalisation at $1200^{\circ} \mathrm{C}$, the top of the size range of the cuboids was $20 \mathrm{~nm}$ and this grew to $60 \mathrm{~nm}$ after 4 th pass and to $80 \mathrm{~nm}$ in the final product. Similar behaviour was observed in Steel V-Nb-Ti where the cuboids seen after equalisation at $1050^{\circ} \mathrm{C}$ and $1100^{\circ} \mathrm{C}$ were larger than those seen after equalisation at $1200^{\circ} \mathrm{C}$, at which temperature they appeared to be going into solution.

\section{Fine precipitates}

These were only observed in the final product of each of the four steels and were in the size range $4-15 \mathrm{~nm}$. They appeared to be random particles and interphase precipitation was not observed. In the present studies, they are considered to be responsible for dispersion strengthening and are discussed in detail elsewhere ${ }^{29}$.

\subsection{EDX and PEELS Analysis}

\section{Dendrites, Plates and Irregularly Shaped Particles}

These were initially seen after casting but persisted to the final product. In Steel V-Ti, the large cuboids had an $\mathrm{Ti} /(\mathrm{V}+\mathrm{Ti})$ atomic ratio of 0.93 , while the dendrites, which were particularly noticeable in Steel V-Nb-Ti, contained almost the same concentrations of $\mathrm{Nb}$ and $\mathrm{Ti}$, but less $\mathrm{V}$.The atomic ratios were $\mathrm{V} /(\mathrm{V}+\mathrm{Nb}+\mathrm{Ti})$ of $0.25, \mathrm{Nb} /(\mathrm{V}+\mathrm{Nb}+\mathrm{Ti})$ of 0.37 and $\mathrm{Ti} /(\mathrm{V}+\mathrm{Nb}+\mathrm{Ti})$ of $0.38^{31,32}$.

\section{Cruciforms}

EDX analysis of $\sim 25$ cruciform particles of Steel V-Ti after equalisation at $1050^{\circ} \mathrm{C}$ gave an average $\mathrm{Ti} /(\mathrm{Ti}+\mathrm{V})$ atomic ratio of 0.30 , which increased to 0.40 following equalisation at $1100^{\circ} \mathrm{C}$. After the same treatment, PEELS analysis of eight randomly selected cruciform precipitates provided data on both metallic and light elements. Fig 10 shows that the $N /(\mathrm{V}+$ Ti) atomic ratio for both the centre and the legs (or arms) of the cruciform were in the range 
0.90 to 1.1 , with an average value of 0.99 . $\mathrm{The} \mathrm{Ti} /(\mathrm{V}+\mathrm{Ti})$ average atomic ratio was 0.44 compared with the ratio of 0.40 given by the above EDX analysis. These compositional results from the cruciforms in Steel V-Ti, show that they are essentially stoichiometric nitrides. Fig 10 shows that the $\mathrm{N} /(\mathrm{V}+\mathrm{Ti})$ atomic ratio is similar in the centre and arms of the cruciforms. The Ti level is normally greater in the arms but there are a significant number of cases where it is the same in the centre and the arms. Figs 11 and 12 show data collected from two cruciform particles as simultaneous annular dark field (ADF) STEM images and x-ray maps. Figs $11 \mathrm{a}$ and $12 \mathrm{a}$ show the ADF images. Figs.11b and $12 \mathrm{~b}$ show Ti $\mathrm{K}_{\alpha} \mathrm{X}$-ray distribution maps, while Figs $11 \mathrm{c}$ and $12 \mathrm{c}$ show the combined $\mathrm{V} \mathrm{K}_{\alpha}$ and $\mathrm{Ti} \mathrm{K}_{\beta}$ distribution maps. From the latter, the $\mathrm{V} \mathrm{K}_{\alpha}$ map alone can be obtained by subtracting the Ti $\mathrm{K}_{\alpha}$ map scaled by the ratio of the $\mathrm{Ti} \mathrm{K}_{\beta}$ intensity to the Ti $\mathrm{K}_{\alpha}$ intensity, available from tables ${ }^{38}$. The intensities in such maps are determined by the thickness as well as the composition. By forming the ratio $\mathrm{Ti} /(\mathrm{V}+\mathrm{Ti})$, the thickness dependence is removed and a concentration map is obtained as in Figs 11d and 12d. The corresponding V concentration maps are shown in Figs 11e and 12e. It can be seen that the cruciform in Fig 11 is Ti rich in the centre, whereas that in Fig 12 is richer in $\mathrm{Ti}$ at the edges of the arms. This suggests strong partitioning of $\mathrm{Ti}$. However, the titanium levels are quite different from those in the (core + cap) $\mathrm{Ti}-\mathrm{Nb}$ precipitates, in Figlb and considered in previous work on Nb-Ti steels ${ }^{16}$. Compared to Steel V-Ti, the vanadium content of the cruciforms in Steel V-Nb-Ti was significantly reduced by the addition of niobium. For Steel V-Ti, the average atomic ratio of $\mathrm{V} /(\mathrm{V}+\mathrm{Ti})$ was 0.70 for $1050^{\circ} \mathrm{C}$ equalisation and 0.60 for $1100^{\circ} \mathrm{C}$ equalisation, whereas for Steel $\mathrm{V}-\mathrm{Nb}-\mathrm{Ti}$, the average atomic ratio of $\mathrm{V} /(\mathrm{V}+\mathrm{Nb}+\mathrm{Ti})$ was 0.39 for $1050^{\circ} \mathrm{C}$ equalisation, 0.32 for $1100^{\circ} \mathrm{C}$ and 0.29 for $1200^{\circ} \mathrm{C}$ equalisation. The particles precipitated at the lowest equalisation temperature therefore had a higher $\mathrm{V} /(\mathrm{V}+\mathrm{Nb}+\mathrm{Ti})$ atomic ratio and a lower $\mathrm{Ti} /(\mathrm{V}+\mathrm{Nb}+\mathrm{Ti})$ than the particles associated with the higher equalisation temperature ${ }^{31}$.Like 
the $\mathrm{Ti} /(\mathrm{V}+\mathrm{Nb}+\mathrm{Ti})$ ratio, the $\mathrm{Nb} /(\mathrm{V}+\mathrm{Nb}+\mathrm{Ti})$ ratio also decreased, from $0.37\left(1050^{\circ} \mathrm{C}\right)$ to 0.32 $\left(1100^{\circ} \mathrm{C}\right)$ and 0.24 after a $1200^{\circ} \mathrm{C}$ treatment.

\section{Cuboidal particles in rows.}

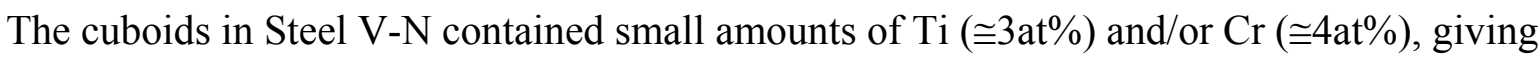
rise to small edges from $\mathrm{Cr}$ and $\mathrm{Ti}$ in the PEELS spectra. The atomic ratio $\mathrm{N} /(\mathrm{Cr}+\mathrm{V}+\mathrm{Ti})$ was $0.95-0.98$, indicting an almost stoichiometric composition for these cuboids.

In Steel V-Ti, the EDX spectra of the cuboids gave an atomic ratio of $\mathrm{Ti} /(\mathrm{V}+\mathrm{Ti})$ which varied from 0.2 to 0.3 , after $1050^{\circ} \mathrm{C}$, to $0.40-0.55$ after equalisation both at $1100^{\circ} \mathrm{C}$ and $1200^{\circ} \mathrm{C}$. These ratios are similar to those found for cruciforms in the same specimens. The PEELS data for Steel V-Ti, taken after equalisation at $1100^{\circ} \mathrm{C}$ for six cuboids taken at random from four different sets of rows, as indicated in Fig 13, is given in Fig 14. The average values of $\mathrm{N} /(\mathrm{V}+\mathrm{Ti})$ and $\mathrm{Ti} /(\mathrm{V}+\mathrm{Ti})$ atomic ratios were 0.96 and 0.45 respectively, while the $\mathrm{Ti} /(\mathrm{V}+\mathrm{Ti})$ atomic ratio determined by EDX was 0.45 , which is in excellent agreement from the small data set involved in the PEELS analysis where the error in the atomic ratio data was $\pm 0.05 \%$. EDX showed that the cuboids in Steel V-Nb equalised at $1050^{\circ} \mathrm{C}$ and $1100^{\circ} \mathrm{C}$ had an atomic ratio $\mathrm{V} /(\mathrm{V}+\mathrm{Nb})$ in the range $0.1-0.45$. Specimens taken after the $4^{\text {th }}$ pass for the higher equalisation temperature, indicated that the range had changed to $0.3-0.4$, while in the final product it had risen to $0.55-0.85$. Cuboids were also observed in

Steel V-Nb-Ti. After equalisation and after the $4^{\text {th }}$ pass, the ratio $\mathrm{V} /(\mathrm{V}+\mathrm{Nb}+\mathrm{Ti})$ was 0.35 0.45 for equalisation at $1050^{\circ} \mathrm{C}, 0.2-0.4$ for equalisation at $1100^{\circ} \mathrm{C}$ and $0.25-0.4$ for equalisation at $1200^{\circ} \mathrm{C}$. This ratio was unchanged after the $4^{\text {th }}$ pass, irrespective of equalisation temperature.

\section{Fine precipitates.}

For Steel V-N, analysis of the PEELS data gave the average composition of particles in the range $4-15 \mathrm{~nm}$, as sub-stoichiometric $\mathrm{V}(\mathrm{C}, \mathrm{N})$, with a crystalline $\mathrm{C} /$ metal ratio of $\sim 0.08$, while 
N/Metal was $0.82^{25}$. For Steel V-Ti, this ratio was 0.82 , while for Steel V-Nb and for Steel V-Nb-Ti, it was 0.66 .

\subsection{Atomic Ratio Variations with Particle Type}

Tables 4 and 5 summarise data on the average atomic ratios for mainly cuboids and cruciform particles analysed from the most complex steel in the study, which contained additions of $\mathrm{V}$, $\mathrm{Nb}$ and $\mathrm{Ti}$. In this work, this steel was considered as an example of the compositional changes found, for selected samples, as the particles evolved through casting, equalisation, after rolling pass 4 and in the final $7 \mathrm{~mm}$ thick strip. Up to eight particles were analysed in each condition. In the following EDX data for Steel $\mathrm{V}-\mathrm{Nb}-\mathrm{Ti}, \mathrm{V}+\mathrm{Nb}+\mathrm{Ti}$ is designated as $\mathrm{M}$. Table 4 shows that as the equalisation temperature increased, the cuboids became richer in titanium, slightly lower in niobium and significantly lower in vanadium. The cruciforms analysed after $1100^{\circ} \mathrm{C}$ equalisation, by comparison, contained the same level of titanium as the cuboids equalised at $1100^{\circ} \mathrm{C}$, but much more niobium and much less vanadium. Analytical data taken after rolling pass 4 and taken from the finished strip are presented in Table 5.Considering data from both Tables 4 and 5 and comparing cruciforms and cuboids which having been equalised at $1100^{\circ} \mathrm{C}$, the $\mathrm{Ti} / \mathrm{M}$ atomic ratio is fairly stable in the cruciforms after equalisation, the $4^{\text {th }}$ pass and final strip, but decreases in the cuboids, while in final strip, the latter contain significantly more vanadium.

\section{Discussion}

The direct charging process removes the need to cool the continuously cast steel to room temperature prior to reheating before rolling, and hence reduces the number of times the steel transforms from $\gamma \rightarrow \alpha$ and re-transforms from $\alpha \rightarrow \gamma$. In addition, the number of rolling passes necessary to reduce the as-cast thickness to the final strip, in this work, $80 \mathrm{~mm}$ to a $7 \mathrm{~mm}$ final product thickness, is much less than in conventional processing starting with a $250 \mathrm{~mm}$ thick slab. However, one of the concerns is that these modifications to the process may result in more microstructural features of the as-cast microstructure being carried through to the final 
stages of processing. For example, this could result in large precipitates, which formed early in the process, removing vanadium and nitrogen atoms and thereby reducing the volume fraction of dispersion strengthening size particles formed in ferrite. Examples of such large precipitates in the form of dendrites and plates are seen in Figs 3 to 4. Similar features have been reported by, for example, Chen et al in concast as- cast V-Ti and Nb-Ti steels ${ }^{8}$ and by Priestner in Ti- Nb-V steels ${ }^{7}$.However, with a similar carbon level of $<0.065 \mathrm{wt} \%$ chosen for the steels studied in the present work, Priestner would predict the absence of substantial amounts of eutectic $\mathrm{NbC}$ in Steels $\mathrm{V}-\mathrm{Nb}$ and $\mathrm{V}-\mathrm{Nb}-\mathrm{Ti}^{7,12}$. While large precipitates present in the as-cast condition of the DCTS are carried through to the final strip, there is no evidence to suggest that the mechanical and toughness properties of the final product are significantly different from similar conventional controlled rolled steels.

Other microstructural features which will reduce the amount of $\mathrm{V}$ available for the dispersion strengthening role are cruciforms and cuboids. With the exception of Steel V-Ti, cuboids were not observed in the as-cast specimens in the present work. They only appeared following equalisation at a temperature below the calculated solubility limit for V-Ti-N particles. Cruciforms were not seen in any of the four as-cast steel samples.

While cruciform particles have been reported in the literature in a number of alloy and microalloyed steels, some containing $\mathrm{Cr}^{39}$, they have most commonly been noted in microalloyed steels containing titanium ${ }^{1,13,15,16}$. Steel V-N in this work had no specific titanium addition but the analyses showed trace levels of $\mathrm{Ti}$ in all steels without a specific $\mathrm{Ti}$ addition. Effects of trace additions in the range $0.002-0.004 \%$ have been reported by Wang 40 and at a level of $0.0011 \%$ by Poths ${ }^{36}$. The level in the present work was in the range 0.002 to $0.003 \mathrm{wt} \%$. Even at this low level in the bulk, a clear Ti $\mathrm{L}_{2,3}$-edge was present in the EELS spectrum acquired from particles $\sim 20 \mathrm{~nm}$ in size. However, no cruciforms containing Ti were observed in the Steel V-N. The steels which did show cruciforms were Steels V-Ti and V-Nb-Ti, Figs 5 and 6, and these steels contained at least $0.007 \mathrm{wt} \%$ Ti. Therefore, it appears 
that a critical lower level of titanium is necessary in the composition of these steels, before the cruciforms develop.

In earlier work ${ }^{16}$, complex particles with a core of $\mathrm{Ti}(\mathrm{CN})$ and caps were observed, as shown in Fig.1b. The present results on steels containing vanadium and titanium, show no substantial consistent evidence of the core-arm cruciform reported by Feng et al ${ }^{9}$ or the capcore arrangement found in previous work ${ }^{16,19,36,37}$. It is interesting to note the similarity in Steel V-Ti of the $\mathrm{Ti} /(\mathrm{V}+\mathrm{Ti})$ atomic ratio in the cuboidal particles and in the cruciforms, which are much larger in size. This similarity was also found in Steel V- Nb- Ti, Tables 4 and 5. The size difference between the cuboids and the cruciforms suggests that the latter start to nucleate at an earlier stage, but other micrographs suggest that the cruciforms may originate from the growing cuboids, Figs.8 and 9. The fact that neither are observed in the quenched as-cast specimens in Steel V-Nb-Ti, suggests that nucleation of the cruciforms may start prior to transferring to the equalisation furnace and be triggered by supersaturation. This hypothesis is supported by the variation in the V/M ratio from 0.20 (cruciform) to 0.39 (cuboid), for $1100^{\circ} \mathrm{C}$ equalisation. However, when the equalisation temperature was $1200^{\circ} \mathrm{C}$, no cruciforms were observed, but the cuboids had a $\mathrm{V} / \mathrm{M}$ ratio of $\sim 0.32$. Therefore the vanadium content of the cuboid particles increases as precipitation proceeds, but decreases as the equalisation temperature increases. The reason for the difference in size between the cruciforms and the cuboidal particles, which can be seen in Figs. 5, 8 and 9 in a row formation on the boundaries present after equalisation, may be the influence of microsegregation associated with the secondary dendrite arms. Evidence for segregation of vanadium at prior austenite boundaries in an experimental microalloyed steel containing $0.048 \% \mathrm{~V}$ was found by He and Edmonds ${ }^{38}$. They used secondary ion mass spectrometry (SIMS), to produce maps showing concentrations of vanadium, which they had not been able to locate with high resolution TEM. However, under the heat treatment conditions used in their work, no precipitates were observed associated with these boundaries. Priestner 
measured the secondary dendrite arms spacings in TSDR steels and found them to lie in the range $50-100 \mu \mathrm{m}^{7}$. From the number of particles observed in the present work, there is an efficient heterogeneous nucleation of the cuboids at these interfaces, but the high nucleation density restricts their growth. While the larger size of the cruciforms suggests that they nucleate earlier in the process and are less restricted in their growth, they do not appear to have a core of a particle nucleated at a much higher temperature, such as an oxide, sulphide or titanium nitride, as was found in earlier work. ${ }^{1,20,22}$. This is supported by the data given in Fig 10 and in the X-ray composition maps in Figs 11 and 12.

When the quenched as-cast samples of Steel V-Ti were re-heated and equalised for 45 mins, at either $1050^{\circ} \mathrm{C}$ or $1100^{\circ} \mathrm{C}$, and then re-quenched to ambient, cruciform precipitates were not observed. This is in direct contrast to the fact that cruciforms were observed in the directly charged and equalised samples from the same steel. It suggests that the $\gamma \rightarrow \alpha$ phase transformation has a significant influence on the formation of cruciform precipitates and the precipitation mechanism may be associated with the reduction of the supersaturation of the microalloying elements, which in TSDR, is on a finer scale than in conventional processed steel, as noted by the smaller secondary dendrite arms spacings. It was noted that the cruciforms were significantly smaller in Steel V-Ti-Nb than in Steel V-Ti. For $1050^{\circ} \mathrm{C}$ equalisation, the arm length of the cruciform particles was 20-50nm in Steel V-Ti and 20$40 \mathrm{~nm}$ in Steel V-Nb-Ti. For $1100^{\circ} \mathrm{C}$ equalisation, the arm length was $120-250 \mathrm{~nm}$ in Steel VTi and 36-160nm in Steel V-Nb-Ti. The addition of Nb, combined with the lower level of nitrogen at $0.01 \mathrm{wt} \%$, therefore, appears to have an important influence on the formation of these precipitates. Recent work on the precipitation of titanium nitride in thin-slab cast HSLA steels, where titanium levels were in the range 0.008 to 0.048 wt. $\%$, with nitrogen up to 0.016 $w t \%$, reported only TiN with a cubic morphology ${ }^{39}$. The highest vanadium level in these steels was $0.005 \mathrm{wt} \%$ and this level of $\mathrm{V}$ would appear to be below the critical level necessary for the formation of cruciform particles. It would therefore appear that critical levels of 
$>0.007 \%$ for titanium and $>0.005 \%$ vanadium are necessary for the formation of cruciform particles.

The size of the cuboids in Steel V-Ti decreased with equalisation temperature from 10-50 nm after $1100^{\circ} \mathrm{C}$ to $7-20 \mathrm{~nm}$ after $1200^{\circ} \mathrm{C}$. Also following equalisation at $1200^{\circ} \mathrm{C}$, the maximum size of the cuboids increased from $20 \mathrm{~nm}$ to $60 \mathrm{~nm}$ at the end of the $4^{\text {th }}$ pass to $80 \mathrm{~nm}$ in the final product. No significant change in ferrite grain size was associated with either the change in equalisation temperature or the average cuboidal size, Table 3. However, the cuboids, which appear to be associated with prior boundaries, Figs 5, 8 9, are considered to have an influence on the austenite grain size, which in turn determines the ferrite grain size. Therefore the combination of size and volume fraction of the cuboids, even at the highest equalisation temperature, is sufficient to ensure that there is control of austenite grain growth which, as is seen in Table 3, gives an average ferrite grain size of 4.5 to $6.8 \mu \mathrm{m}$ in the final product. After equalisation the cuboids also became richer in titanium as the equalisation temperature increased from $1050^{\circ} \mathrm{C}$, Steel V-Ti, Ti/(V+Ti) $=0.2-0.3$ and Steel V-Nb-Ti, $\mathrm{Ti} /(\mathrm{V}+\mathrm{Nb}+\mathrm{Ti})=0.29$, to $1200^{\circ} \mathrm{C}$, Steel V-Ti, Ti/(V+Ti) $=0.4-0.55$, Steel V-Nb-Ti, $\mathrm{Ti} /(\mathrm{V}+\mathrm{Nb}+\mathrm{Ti})=0.36-0.56$, while the $\mathrm{N} /$ metal atomic ratio was in the range $0.96-0.99$ for all the cuboids examined in the four steels. The ChemSage calculations are in satisfactory agreement with this data. ${ }^{28,31,32}$. Also the cuboid composition was very stable, as shown by the data given in Fig 14. One of the most important observations in the present investigation is that, with the exception of Steel V-Nb, there is an absence of a significant carbon content in "carbonitrides" particle analysed using PEELS. While the $\mathrm{V}, \mathrm{Nb}$ and Ti contents of the particles changed as the TSDR processing progressed, the particles, regardless of their morphology, were essentially nitrides. This is contrary to the predictions of classical thermodynamics and equilibrium solubility data, as described by, for example, Keown and Wilson ${ }^{45}$, Gladman ${ }^{46}$ and Pickering ${ }^{47}$. However another view, following computations undertaken by Woodhead ${ }^{48}$, concluded that particles formed randomly in vanadium 
microalloyed steels, either austenite or ferrite, are close to $\mathrm{VN}$ and are unlikely to be $\mathrm{V}(\mathrm{C}, \mathrm{N})$. This conclusion is also supported by a thermodynamic analysis of the Fe-V-C-N system undertaken by Roberts and Sandberg ${ }^{49}$ and discussed by Siwecki et al ${ }^{50}$.The Swedish work ${ }^{49,50}$ also predicts that for precipitation in austenite, the vanadium carbonitride phase which is formed is nitrogen rich during virtually the entire reaction. Additionally, they point out that the predictions are based on equilibrium conditions, from which most real situations depart. "While considerable precipitation would be predicted on ageing a supersaturated austenite at $800^{\circ} \mathrm{C}$, it is well established that in practice, decomposition of undeformed $\mathrm{V}$-alloyed austenite is very slow, and during cooling after normal rolling, little or no $\mathrm{V}(\mathrm{C}, \mathrm{N})$ is expected prior to transformation" ${ }^{49}$. "For random precipitation in ferrite, it is predicted that the precipitating phase has a composition which is nearly VN. The entire remaining spectrum of carbonitride compositions is then traversed as the last remnants of nitrogen are consumed and finally, any vanadium remaining in solution will precipitate as $\mathrm{VC}$, until the concentration of vanadium falls below the solubility limit for VC in ferrite" ${ }^{49}$. Clearly, the present observations disagree with the above predictions with regard to the presence of $\mathrm{VN}$ particles following equalisation but before rolling, but are in agreement with the predicted chemical composition of the stoichiometric MN precipitates. It would appear that the observations of cuboids following the equalisation treatment, must be significantly influenced by their mainly heterogeneous nucleation on boundaries, because random, i.e. homogeneously nucleated, $\mathrm{V}$ containing nitrides are not normally expected in undeformed austenite ${ }^{49}$. A further observation in the present work was that no dispersion hardening particles smaller than $\sim 4 \mathrm{~nm}$ were seen. One reason that smaller particles were not observed could be that nitrides which were $\sim 2 \mathrm{~nm}$ in size at the end of the run-out table simulation, grew to $4 \mathrm{~nm}$ during the $600^{\circ} \mathrm{C}$ furnace treatment used to simulate coiling. However, all the steel compositions were chosen to have an excess of microalloying elements relative to nitrogen, and when nitrogen was exhausted, small $(<4 \mathrm{~nm})$ high carbon $\mathrm{M}(\mathrm{C}, \mathrm{N})$ precipitates 
would be expected, but were not observed. Size itself is not a limiting factor in observing the precipitates on the replica since $2 \mathrm{~nm} \mathrm{SiO}$ particles were imaged in the support film of the replica and a $2 \mathrm{~nm} \mathrm{VC}$ or $\mathrm{VN}$ particle would be much more visible than a $2 \mathrm{~nm} \mathrm{SiO}_{x}$ particle. Another possibility is that the carbonitrides and/or carbides are still coherent below $4 \mathrm{~nm}$ in size. It is not clear whether or not coherent precipitates can be extracted by carbon replicas using the same method which has been followed for over 40 years for incoherent precipitates. This analysis of these small particles is discussed in detail in another paper ${ }^{29}$. Large carbides were present as pearlite in the high end-cool temperature final specimens and as bainite in the low end-cool temperature specimens.

With regard to the mechanical properties, the reduction in the lower yield strength in Steel V$\mathrm{Ti}$, which has a small ferrite grain size of $\sim 5 \mu \mathrm{m}$, is directly related to the reduction in the contribution from dispersion strengthening, Table $3^{27,36,37,40}$. In this table it can be seen that the values of $\left(\sigma_{\mathrm{p}}+\sigma_{\mathrm{d}}\right)$ for Steel V-Ti change in the order 86,137,110 MPa with an increase in the equalisation temperature, while for Steel $\mathrm{V}-\mathrm{Ti}-\mathrm{Nb}$, the corresponding figures are $109,147,197 \mathrm{MPa}$. Thus the addition of $0.03 \mathrm{Nb}$ increases substantially the effect of the dispersion of fine particles especially at the higher equalisation temperature.

In Steel V-Ti, the $\left(\sigma_{\mathrm{p}}+\sigma_{\mathrm{d}}\right)$ component of strengthening decreased following $1200^{\circ} \mathrm{C}$ equalisation, whereas this contribution increased with equalisation temperature for Steel V$\mathrm{Nb}$-Ti. For the same equalisation temperatures, a reduction in the lower yield strength was also found between Steel V-Nb and Steel V-Nb-Ti, where in the latter steel, cruciforms were reported. The reduction in lower yield strength when titanium is present in vanadium and niobium steels has been noted in the literature ${ }^{12,15,50,51}$. Others have found that with some compositions, particularly in $\mathrm{V}$ and $\mathrm{Nb}$ free steels, the addition of Ti actually increases the lower yield strength of material produced by the TSDR process compared with that produced by conventional processing ${ }^{52-54}$. However, this effect was found in steels having higher Ti and $\mathrm{C}$ levels than in the present steels. 
One of the concerns in this work is its relevance to commercial practice. It is not clear whether or not the cruciforms are just an artefact due to the simulation process and would therefore not be observed in a commercial process. However, both cruciforms and cuboids have been reported in commercial casts ${ }^{1,55}$.

\section{Conclusions}

In a detailed investigation of the evolution of the precipitates present during the direct charged thin slab process of vanadium based microalloyed steels, it was found that:

(1) dendrites, plate-like particles and laths were observed in all the specimens;

(2) cuboidal particles, frequently associated with boundaries, were found in the as-cast specimen of Steel V-Ti, and after equalisation for all the steels;

(3) cruciform precipitates were observed only in the titanium containing Steels V-Ti and V$\mathrm{Nb}-\mathrm{Ti}$, and were usually associated with prior boundaries: they were not found in the ascast specimens but were found after equalisation at $1050^{\circ} \mathrm{C}$ and $1100^{\circ} \mathrm{C}$ for Steel V-Ti and after equalisation at all three temperatures for Steel V-Nb-Ti;

(4) it appears that critical levels $>0.007 \%$ of titanium and $>0.005 \%$ vanadium are necessary for the formation of cruciforms in the present steels;

(5) cruciforms were carried through to the final stages of processing, and examples of breakaway of the arms were found after rolling;

(6) EDX and PEELS analysis showed that the V/metal ratio increased from the as-cast dendrites and laths, to the cruciforms and cuboids formed at equalisation, to the fine dispersion hardening particles observed only in the final product specimens. All the vanadium based precipitates were essentially nitrides with no substantial carbon content;

(7) PEELS also showed that the cruciforms did not have a core of a stable oxide, sulphide or nitride, the faces of which might have been favourable sites for heterogeneous nucleation of vanadium and/or niobium carbonitride arms or caps; 
(8) compared to Steels V-N and V-Nb, Steels V-Ti and V-Nb-Ti both showed reductions in the lower yield strength due to smaller contributions from the dispersion plus dislocation strengthening components. However, the toughness was improved with titanium additions through smaller ferrite grain size combined with the reduced dispersion strengthening.

\section{Acknowledgements}

The authors would like to acknowledge the support of EPSRC grants GR/M22918 (University of Strathclyde) and GR/M22888 (University of Glasgow), the support in cash and kind from Corus, through Dr. D. Naylor and Vanitec through Mr P.S.Mitchell, and the advice of Dr W.B.Morrison, formerly of British Steel, and a Visiting Professor at the University of Strathclyde, Glasgow.

\section{References}

1 R. Lagneborg, T. Siwecki, S. Zalac and B. Hutchinson, Scan. J. Met., 1999, 28, 186-241

2 E.Hofken, P.Kappes and H.Lax, Stahl u Eisen, 1986,106, 27-33.

3 G.Flemming, P.Knappes, W.Rohde and L.Vogtmann, Stahl u Eisen, 1988,108,25-35.

4 G.Flemming, F.Hofman,W.Rohde and D.Rosenthal,Met.Plant Tech.Int.1993,2,84-96

5 P. J. Lubensky, S. L .Wigman and D. J. Johnson, Microalloying '95, 1995, (Pittsburgh: ISS) $225-233$

6 D. N. Crowther, P.S. Mitchell and W.B. Morrison Proc.Int.Conf.39 $9^{\text {th }}$ Mech. Work. Steel Process. 1998, (Warrendale: ISS/AIME ) 839-848.

7 R. Priestner, Mat.Sci.Forum, 1998, 284-286, 95-104. 
8 Z.Chen, M.H.Loretto and R.C.Cochrane, Mat.Sci.Tech.,1987,3,836-843.

9 B.Feng, T.Chandra and D.P.Dunne, Mat.Forum, 1989,13,139- 146.

10 M. Prikryl, A Kroupa, G.C.Weatherly and S.V.Subramanian, Met.Mat.Trans.1996,27A,1149-1165.

11 S.V.Subramanian and G.C.Weatherly, Titanium technology in microalloyed Steels, (ed.T.N.Baker), 1997,Inst.Mat., London,133-149.

12 P. H. Li, A.K.Ibraheem and R.Priestner, Mat.Sci.Forum,1998, 284-286,517-524.

13 D.C.Houghton, G.C.Weatherly and J.D.Embury, Thermomechanical processing of microalloyed austenite, (ed A.J.DeArdo, G.A.Ratz and P.J.Wray),1982, ,Met.Soc.AIME, Warrendale. Penn., 267-292.

14 R.Priestner and C.Zhou, Iron.Steel,1995, 22,326-332

15 S.Zajac, T.Siwecki, W.B.Hutchinson and M.Attlegård, Met.TransA, 1991,23A, 26812694.

16 He Kejian and T.N.Baker, Titanium technology in microalloyed steels, (ed.T.N.Baker), 1997,Inst.Mat. , London,115-132.

17 Y.Li, D.N.Crowther, J.A.Wilson, A.J.Crowther and T.N.Baker, Proc.EMAG '01, (ed. M Aindow and C.J.Kiely), 2001.183-186, IoP, London,

18 C.Zhou and R. Priestner, ISIJ International, 1996,36,1397-1405

19 A.J.Craven, K.He, L.A.J.Garvie and T.N.Baker, Acta mater.2000, 48, 3857- 3868.

20 W. Saikaly, X. Bano, C.Issartel, G.Rigaut, L.Charrin and A.CharaI, Met. Mat. Trans .A, 2001, 32A, 1939-1947.

21 P.L.Harrison and P.H.Bateson, Titanium technology in microalloyed steels, (ed.T.N.Baker), 1997,Inst.Mat.,London,180-196.

22 E.Essadiqi and M.T.Shehata, Can.Met.Quart.1994, 33, 111-120.

23 H.A.Vogels, P.Konig and K-H Piehl, Archiv. Eisenh. 1964,35,339-351 
24 A.J.Craven, M. M.Cluckie, S.P.Duckworth and T.N.Baker, Ultramicros. 1989,28,330334.

25 J.A.Wilson, A.J.Craven, Y.Li, and T.N.Baker, Proc.EMAG ' 01, (ed. M Aindow and C.J.Kiely), 2001, IoP, London, 183-186.

26 J.A.Wilson, A.J.Craven, Ultramicros.2003,94, 197-207.

27 D.N.Crowther, Y.Li, T.N.Baker, M.J.W.Green, and P.S. Mitchell, Thermomechanical processing of steels, 2000,Inst.Mat.,London,527-536

28 Y.Li, D.N.Crowther P.S.Mitchell and T.N.Baker,Iron Steel Inst. Japan. Inter, 2002,42, 636644.

29 J.A.Wilson, A.J.Craven, Y.Li, and T.N.Baker, submitted to Acta materialia. Manuscript no.A-0316-03-DW

30 Y.Li, D.N.Crowther, P.S.Mitchell and T.N.Baker, Proc. Fourth Inter. Conf HSLA Steels, 2000, ed. G.Liu, F.Wang, Z.Wang and H.Zhang., 2000, Met. Press, Beijing, 326-332. 31 A. J. Rose: Rep. SL/PM/R/S2971/17/98/A, British Steel Plc., Swinden Technology Centre, (1998).

32 A. Cracknell and N. J. Petch: Acta. Meter., 3(1955), 186.

33 F. B. Pickering and T. Gladman: ISI Spec. Rep. (1963), 181.

34 W. B. Leslie: Metall. Trans., 3 (1972), 5.

35 W. B. Morrison and J. A. Chapman: Rosenheim Centenary Conf. The Royal Society, London, (1976), 295.

36 Y.Li, D.N.Crowther, P.S.Mitchell and T.N.Baker, Conf.Proc. , ASM Mat Sol., 2002, 1-11 37 Y.Li, J.A.Wilson, D.N.Crowther, P.S.Mitchell, A.J.Craven and T.N.Baker, submitted to Iron Steel Inst. Japan. Inter.

38 T.P. Schreiber and A.M. Wims X-ray spectroscopy 1982, 11, 42.

39 A.C.Roberts and H.E.Evans, Mechanical behaviour and nuclear applications of stainless steels at elevated temperatures, 1982, Inst. Mats, London, 51-58 
40 S-C Wang, Met. Trans. A, 1993, 24A, 2127-2130

41 R.M. Poths, R.L.Higginson and E.J.Palmiere, Proc.EMAG ' 01, (ed. M Aindow and C.J.Kiely), 2001, IoP, London, 207-210.

42 D.J.Egner,R.C.Cochrane and R.Brydson, Proc.EMAG ' 99,( C.J.Kiely), 1999,IoP,London,447-450.

43 K.He and D.V.Edmonds, Mat.Sci.Tech.,2002,18,289-296.

44 M.T.Nagata, J.G.Speer and D.K.Matlock, Met.Mat.Trans.A, 2002,33A, 3099-3110.

45 S.R.Keown and W.G.Wilson Thermomechanical processing of microalloyed austenite, (ed A.J.DeArdo, G.A.Ratz and P.J.Wray),1982, ,Met.Soc.AIME, Warrendale. Penn., 343-35 46 T. Gladman, The physical metallurgy of microalloyed steels, 1997, IoM. London, 81-135. 47 F. B. Pickering, Titanium technology in microalloyed steels, (ed.T.N.Baker), Inst.Mat., 1997,London,13-43.

48 J.H.Woodhead, Proc.Vanadium' 79, 1979, Vandium International Technical Committee, 49 T.Siewecki, A.Sandberg, W.Roberts, R. Lagneborg, Thermomechanical processing of microalloyed austenite, (ed A.J.DeArdo, G.A.Ratz and P.J.Wray),1982, ,Met.Soc.AIME, Warrendale. Penn., 163-194

50 T.Siewecki, A.Sandberg and W.Roberts, HSLA steels, technology and applications, (ed.. M. Korchynsky), 1984, ASM, Metals Park, Oh. 619-634

51 He Kejian and T.N.Baker, Mat.Sci.Eng.1993, A169, 53-65.

52 H.Tamehiro and H.Nakasugi, Trans. Iron Steel Inst. Japan, 1985,25,315-317.

53 R.K.Gibbs, R .Peterson and B.Parker, Proc.Int. Conf. Processing, microstructure and properties of microalloyed steels, 1992, ISS-AIME, Warrendale, Pa, 201-207.

54 V. Leroy and J. C. Herman, Conf. Proc. Microalloying '95, (ed A. J. DeArdo), 1995, Iron Steel Inst., Pittsburgh, Pa, 213-223.

55 S. Zajac, T.Siewecki, B. Hutchinson and M.Attlegård, Met. Trans. A, 1991, 22A, 26812694 


\section{Figures}

1 TEM of carbon extraction replicas, (a) cruciform particle (b) core plus caps particle

2 Schematic diagram showing the process route adopted to simulate thin slab direct charging in the present study.

3 TEM micrograph showing dendrites in Steel V-Nb-Ti after casting

4 TEM micrograph showing dendrites in Steel $\mathrm{V}-\mathrm{Nb}-\mathrm{Ti}$ after equalisation at $1050^{\circ} \mathrm{C}$, and taken after pass $4, \mathrm{WQ}$,

5 TEM micrograph showing a cruciform particle and net-work of cuboids, Steel V-Ti , equalised at $1100^{\circ} \mathrm{C}$ then WQ

6. TEM micrograph showing a cruciform particles, Steel V-Nb-Ti equalised at $1100^{\circ} \mathrm{C}$, and taken after pass $4, W Q$

7 TEM micrograph showing a cruciform starting to break- up,in Steel V-Ti ,

8 TEM micrograph showing a row of cuboidal particles, Steel V-N, in the as-cast and quenched specimen.

9 TEM micrograph showing agglomeration of cuboidal particles in Steel V-Ti after equalisation at $1100^{\circ} \mathrm{C}$

10 Graphs showing $\mathrm{N} /(\mathrm{V}+\mathrm{Ti})$ compositional ratios for eight cruciform particles (a) centre and (b) legs.

11 Concentration maps for particle showing high Ti counts at the centre(a) Annular dark field STEM image (b)TiK $\alpha$ Counts (c) VK $\alpha+\mathrm{TiK} \beta$ counts (d)Ti/(V+Ti) concentration map (e) $\mathrm{V} /(\mathrm{V}+\mathrm{Ti})$ Concentration map.

12 Concentration maps for particle showing high Ti counts at the edges of arms (a) Annular dark field STEM image (b) TiK $\alpha$ Counts (c) VK $\alpha+\operatorname{TiK} \beta$ counts (d)Ti/(V+Ti) concentration map (e) $\mathrm{V} /(\mathrm{V}+\mathrm{Ti})$ Concentration map.

13 Dark field images of six randomly selected cuboidal particles, labelled a) to f)

14 Graphs showing compositional ratios for six cuboidal particles in Fig 13: (a) Ti/(V+Ti) and

b) $\mathrm{N} /(\mathrm{V}+\mathrm{Ti})$ 
Table 1 The compositions of the steels (wt.\%)

\begin{tabular}{|c|c|c|c|c|c|c|c|c|}
\hline Steel & $\mathbf{C}$ & $\mathbf{S i}$ & $\mathbf{M n}$ & $\mathbf{P}$ & $\mathbf{S}$ & $\mathbf{C r}$ & $\mathbf{M o}$ & $\mathbf{N i}$ \\
\hline $\mathbf{V}-\mathbf{N}$ & 0.068 & 0.37 & 1.40 & 0.014 & 0.005 & 0.09 & 0.02 & 0.07 \\
\hline $\mathbf{V}-\mathbf{T i}$ & 0.065 & 0.47 & 1.44 & 0.015 & 0.006 & 0.09 & 0.02 & 0.07 \\
\hline $\mathbf{V - N b}$ & 0.061 & 0.48 & 1.48 & 0.015 & 0.005 & & & \\
\hline $\mathbf{V - T i - N b}$ & 0.056 & 0.51 & 1.45 & 0.016 & 0.005 & & & \\
\hline Steel & $\mathbf{A l}$ & $\mathbf{B}$ & $\mathbf{C u}$ & $\mathbf{N}$ & $\mathbf{N b}$ & $\mathbf{T i}$ & $\mathbf{V}$ & $\mathbf{0}$ \\
\hline $\mathbf{V}-\mathbf{N}$ & 0.025 & $<0.0005$ & 0.07 & 0.020 & $<0.005$ & 0.002 & 0.10 & 0.0096 \\
\hline $\mathbf{V}-\mathbf{T i}$ & 0.026 & $<0.0005$ & 0.07 & 0.017 & $<0.005$ & 0.009 & 0.10 & 0.0058 \\
\hline $\mathbf{V}-\mathbf{N b}$ & 0.035 & & & 0.011 & 0.03 & 0.003 & 0.11 & 0.007 \\
\hline $\mathbf{V - T i - N b}$ & 0.022 & & & 0.011 & 0.031 & 0.008 & 0.11 & \\
& & & & & & & & \\
\hline
\end{tabular}

Table 2 Processing conditions for the steels

\begin{tabular}{|l|c|c|c|c|c|c|}
\hline \multicolumn{1}{|c|}{ Steel } & \multicolumn{3}{|c|}{ Steel V-N } & \multicolumn{3}{c|}{ Steel V-Nb } \\
\hline Furnace entry T, ${ }^{\circ} \mathrm{C}$ & 899 & 980 & 932 & 1026 & 1104 & 997 \\
\hline Equalisation $\mathrm{T},{ }^{\circ} \mathrm{C}$ & 1050 & 1100 & 1200 & 1050 & 1100 & 1200 \\
\hline Equalisation time, min & 60 & 32 & 30 & 48 & 53 & 54 \\
\hline
\end{tabular}

\begin{tabular}{|l|c|c|c|c|c|c|}
\hline \multicolumn{1}{|c|}{ Steel } & \multicolumn{3}{|c|}{ Steel V-Ti } & \multicolumn{3}{c|}{ Steel V- Nb- Ti } \\
\hline Furnace entry T, ${ }^{\circ} \mathrm{C}$ & 957 & 1095 & 916 & 1003 & 1066 & 1037 \\
\hline Equalisation $\mathrm{T},{ }^{\circ} \mathrm{C}$ & 1050 & 1100 & 1200 & 1050 & 1100 & 1200 \\
\hline Equalisation time, min & 41 & 47 & 43 & 47 & 49 & 50 \\
\hline
\end{tabular}


Table 3 Mechanical and Toughness Properties

\begin{tabular}{|c|c|c|c|c|c|c|c|c|c|}
\hline Steel & $\begin{array}{l}\text { Equal } \\
\text { Temp } \\
{ }^{\circ} \mathrm{C} .\end{array}$ & $\begin{array}{l}\text { End } \\
\text { Cool } \\
\text { Temp } \\
{ }^{\circ} \mathrm{C} .\end{array}$ & $\begin{array}{l}\text { Ave } \\
\text { LYS } \\
\text { MPa }\end{array}$ & $\begin{array}{l}\text { Ave } \\
\text { UTS } \\
\text { MPa }\end{array}$ & \begin{tabular}{|l|} 
Ave \\
El \%
\end{tabular} & $\begin{array}{l}\text { Ave. } \\
\text { Charpy } \\
\mathrm{J} \text { at - } \\
20^{\circ} \mathrm{C}\end{array}$ & $\begin{array}{l}13 \mathrm{~J} \\
\text { ITT } \\
{ }^{\circ} \mathrm{C}\end{array}$ & $\begin{array}{l}\alpha \\
\text { Grain } \\
\text { Size } \\
\mu \mathrm{m}\end{array}$ & $\begin{array}{l}\sigma_{p}+\sigma_{d} \\
M P a\end{array}$ \\
\hline \multirow[t]{3}{*}{ V-N } & 1200 & 700 & 518 & 642 & 19.5 & 37 & -60 & 6.8 & 173 \\
\hline & 1100 & 511 & 600 & 703 & 20 & 20 & -45 & 5.7 & 236 \\
\hline & 1050 & 602 & 557 & 644 & 24 & 43 & -85 & 6.2 & 200 \\
\hline \multirow[t]{3}{*}{ V-Ti } & 1200 & 643 & 461 & 571 & 26.5 & 45 & -100 & 6.6 & 110 \\
\hline & 1100 & 537 & 522 & 609 & 18 & 43 & -90 & 4.8 & 137 \\
\hline & 1050 & 590 & 463 & 579 & 22 & 68 & -120 & 5.7 & 86 \\
\hline \multirow[t]{3}{*}{ V-Nb } & 1200 & 558 & 632 & 740 & 19 & 39 & -95 & 5.5 & 247 \\
\hline & 1100 & 647 & 543 & 653 & 17 & 45 & -100 & 5.6 & 166 \\
\hline & 1050 & 693 & 573 & 673 & 22.5 & 52 & -105 & 4.5 & 166 \\
\hline \multirow[t]{3}{*}{ V-Nb-Ti } & 1200 & 504 & 590 & 695 & 20. & 43 & -90 & 5.2 & 197 \\
\hline & 1100 & 603 & 547 & 646 & 24 & 63 & -100 & 4.8 & 147 \\
\hline & 1050 & 678 & 496 & 599 & 24 & 76 & -75 & 5.9 & 109 \\
\hline
\end{tabular}


Table 4 Average Atomic Ratios of Microalloying Elements in Particles after casting and after Equalisation at $1050^{\circ} \mathrm{C} 1100^{\circ} \mathrm{C}$ or $1200^{\circ} \mathrm{C}$ for Steel V Nb Ti. $(\mathrm{M}=\mathrm{V}+\mathrm{Nb}+\mathrm{Ti})$.

\begin{tabular}{|l|l|l|l|l|l|}
\hline $\begin{array}{l}\text { Element } \\
/ \mathbf{M}\end{array}$ & $\begin{array}{l}\text { As-Cast } \\
\text { dendrite }\end{array}$ & $\begin{array}{l}1050^{\circ} \mathrm{C} \\
\text { cuboids }\end{array}$ & $\begin{array}{l}1100^{\circ} \mathrm{C} \\
\text { cuboids }\end{array}$ & $\begin{array}{l}1100^{\circ} \mathrm{C} \\
\text { cruciforms }\end{array}$ & $\begin{array}{l}1200^{\circ} \mathrm{C} \\
\text { cuboids }\end{array}$ \\
\hline $\mathbf{T i} / \mathbf{M}$ & 0.377 & 0.293 & 0.383 & 0.384 & 0.463 \\
\hline $\mathbf{N b} / \mathbf{M}$ & 0.361 & 0.251 & 0.234 & 0.415 & 0.223 \\
\hline $\mathbf{V} / \mathbf{M}$ & 0.261 & 0.456 & 0.385 & 0.201 & 0.315 \\
\hline
\end{tabular}

Table 5 Average Atomic Ratios of Microalloying Elements in Particles analysed after the $4^{\text {th }}$ pass following Equalisation at $1050^{\circ} \mathrm{C}$ or $1100^{\circ} \mathrm{C}$, and analysed in the final strip after Equalisation at $1100^{\circ} \mathrm{C}$ for Steel $\mathrm{V} \mathrm{Nb} \mathrm{Ti} . \quad(\mathrm{M}=\mathrm{V}+\mathrm{Nb}+\mathrm{Ti})$.

\begin{tabular}{|l|l|c|c|c|c|c|c|}
\hline $\begin{array}{c}\text { Element } \\
/ \mathbf{M}\end{array}$ & $\begin{array}{l}1050^{\circ} \mathrm{C} \\
4^{\text {th }} \text { pass }\end{array}$ & $\begin{array}{c}1050^{\circ} \mathrm{C} \\
4^{\text {th }} \text { pass }\end{array}$ & $\begin{array}{l}1100^{\circ} \mathrm{C} \\
4^{\text {th }} \text { pass }\end{array}$ & $\begin{array}{l}1100^{\circ} \mathrm{C} \\
4^{\text {th }} \text { pass }\end{array}$ & $\begin{array}{l}1100^{\circ} \mathrm{C} \\
\text { final }\end{array}$ & $\begin{array}{l}1100^{\circ} \mathrm{C} \\
\text { final }\end{array}$ & $\begin{array}{l}1100^{\circ} \mathrm{C} \\
\text { final }\end{array}$ \\
\hline & cuboid & cruciform & cuboid & cruciform & cuboid & cruciform & small \\
\hline $\mathbf{T i} / \mathbf{M}$ & 0.248 & 0.236 & 0.413 & 0.388 & 0.173 & 0.361 & 0.010 \\
\hline $\mathbf{N b} / \mathbf{M}$ & 0.335 & 0.392 & 0.302 & 0.320 & 0.317 & 0.369 & 0.194 \\
\hline $\mathbf{V} / \mathbf{M}$ & 0.384 & 0.372 & 0.285 & 0.289 & 0.510 & 0.270 & 0.730 \\
\hline
\end{tabular}




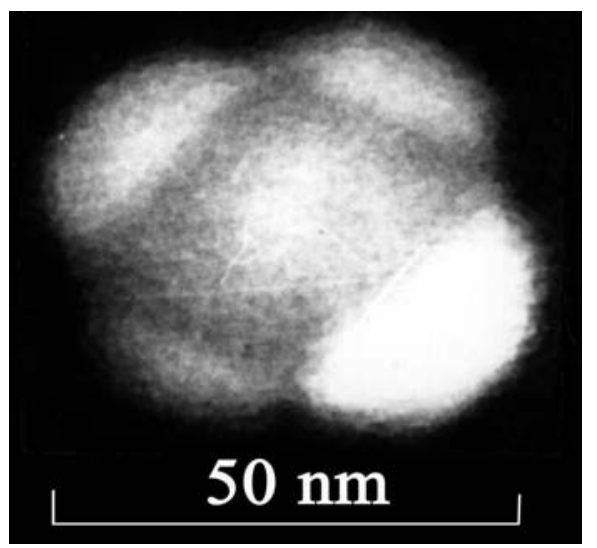

Fig $1 b$ Core plus caps

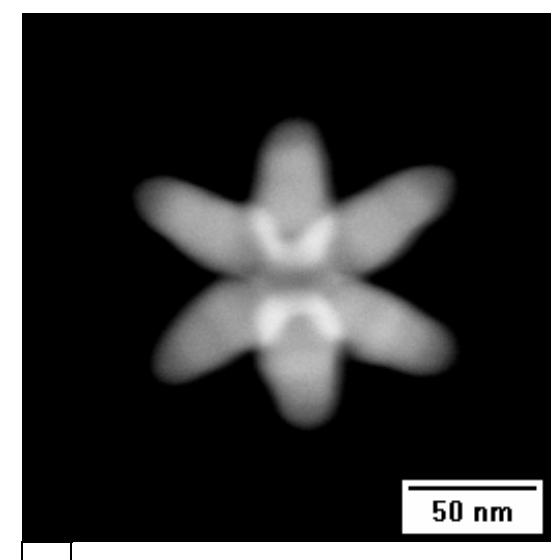

Fig 1a Cruciform particle

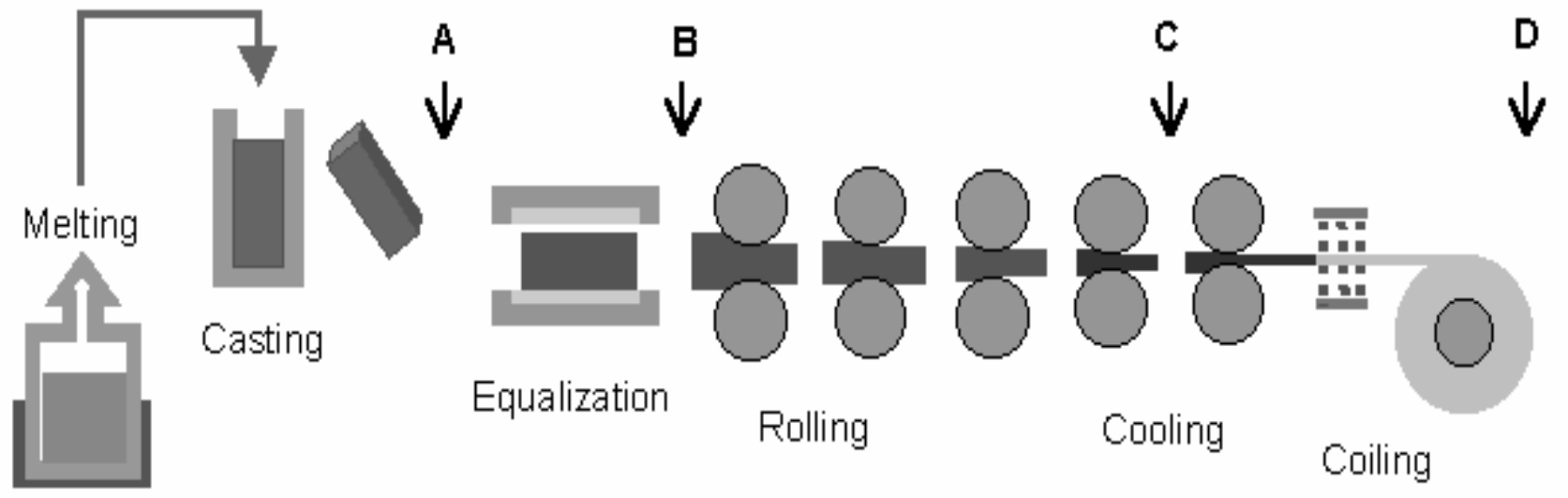

Fig. 2 Schematic diagram showing the thin slab direct rolling processing adopted in this study. 


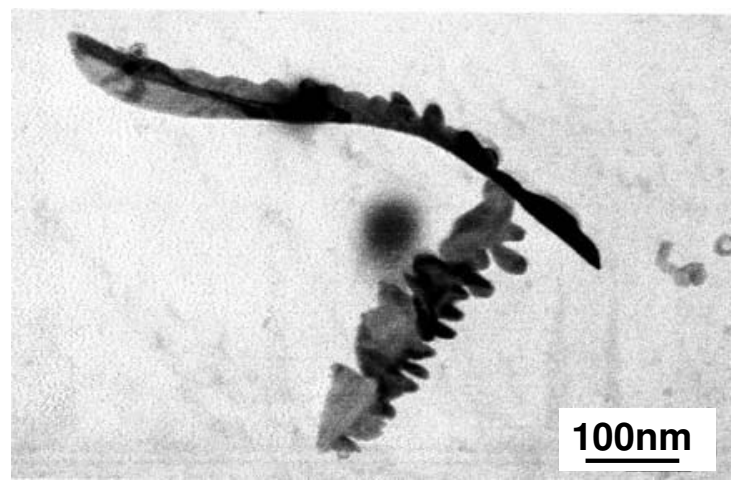

Fig 3

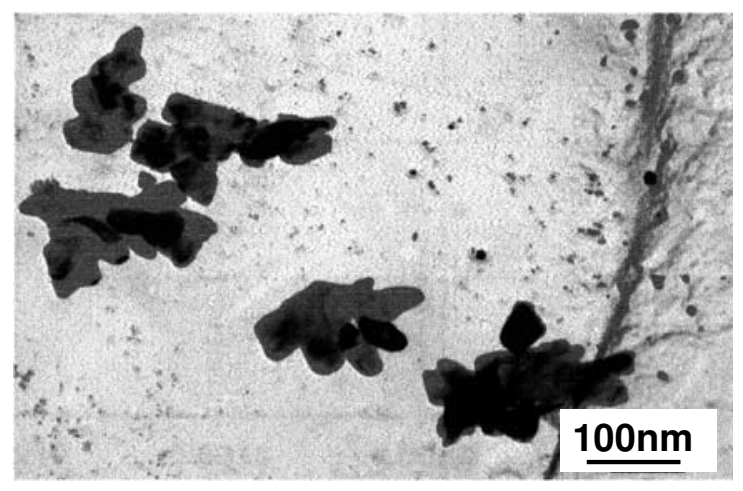

Fig 4

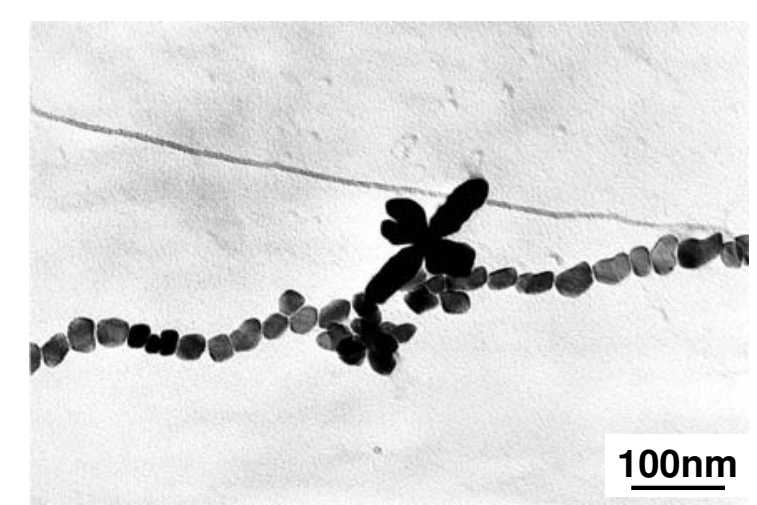

Fig 5

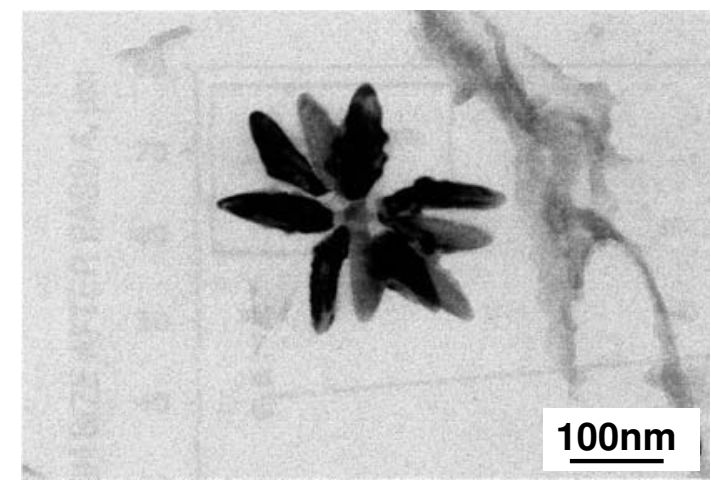

Fig 6

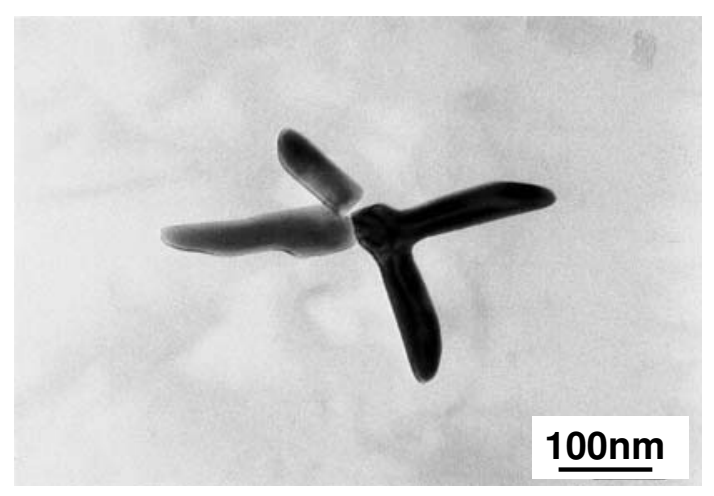

Fig7

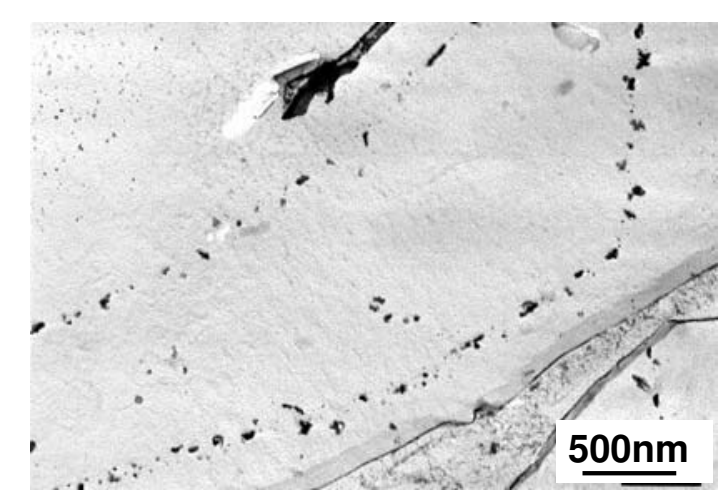

Fig 8 


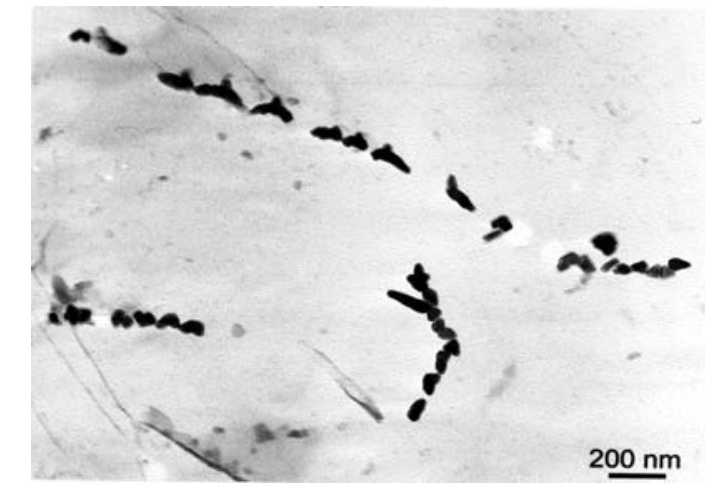

Fig 9

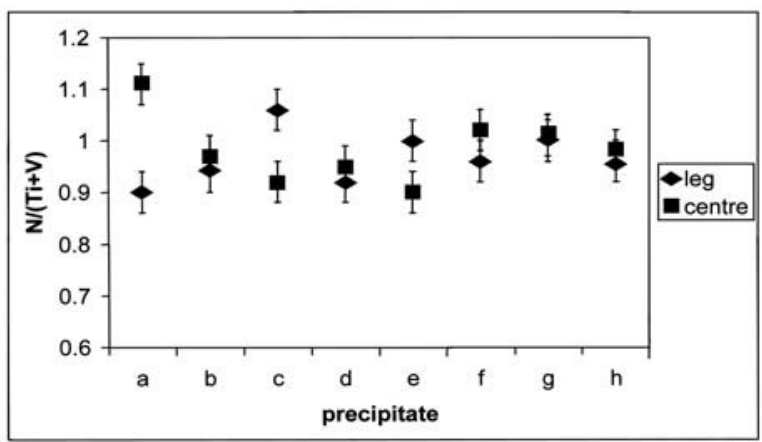

Fig 10 


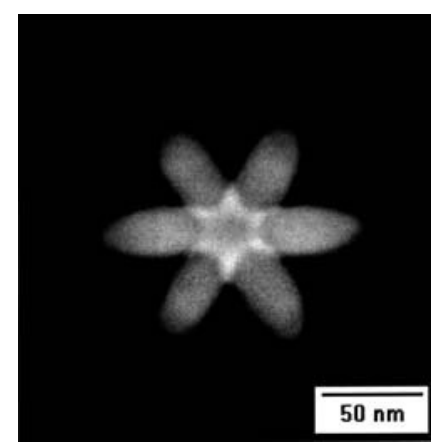

a. Annular dark field STEM image

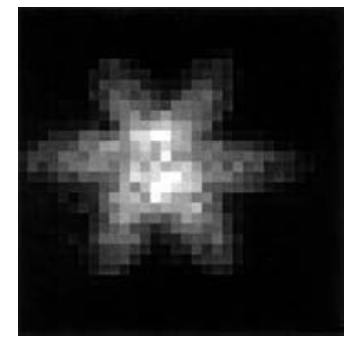

b. CountsTi $\alpha$

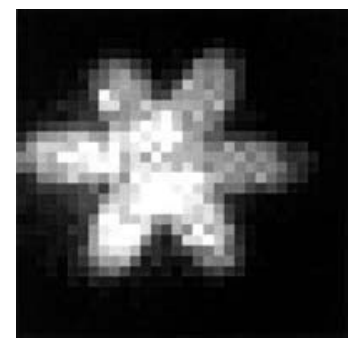

c. CountsTi $\beta+\mathrm{VK}_{\alpha}$

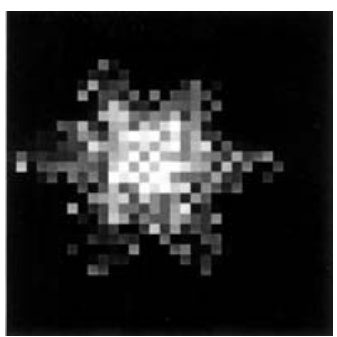

d. $\mathrm{Ti} /(\mathrm{Ti}+\mathrm{V})$ Concentration map

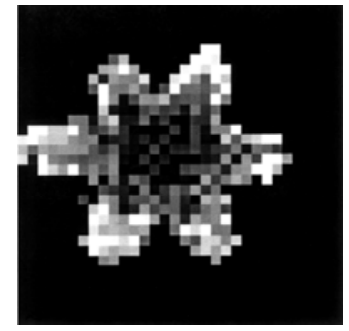

e. $\mathrm{V} /(\mathrm{Ti}+\mathrm{V})$ Concentration map

Fig 11

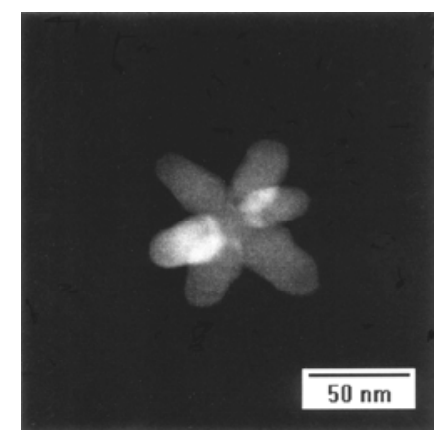

a. Annular dark field STEM

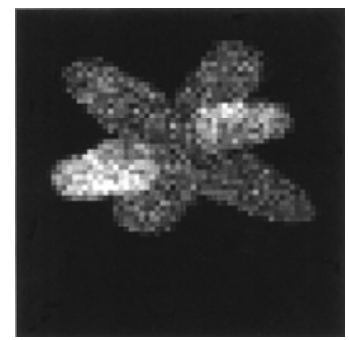

b. CountsTi $\alpha$

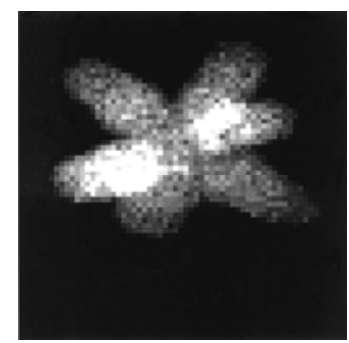

CountsTi $\beta+\mathrm{VK}_{\alpha}$

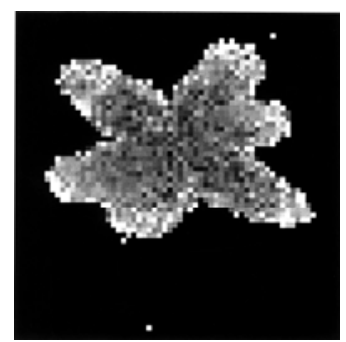

d. $\mathrm{Ti} /(\mathrm{Ti}+\mathrm{V})$ Concentration map

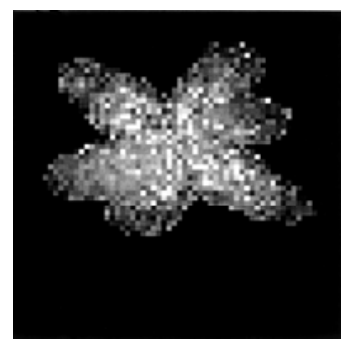

e. $\mathrm{V} /(\mathrm{Ti}+\mathrm{V})$ Concentration map 

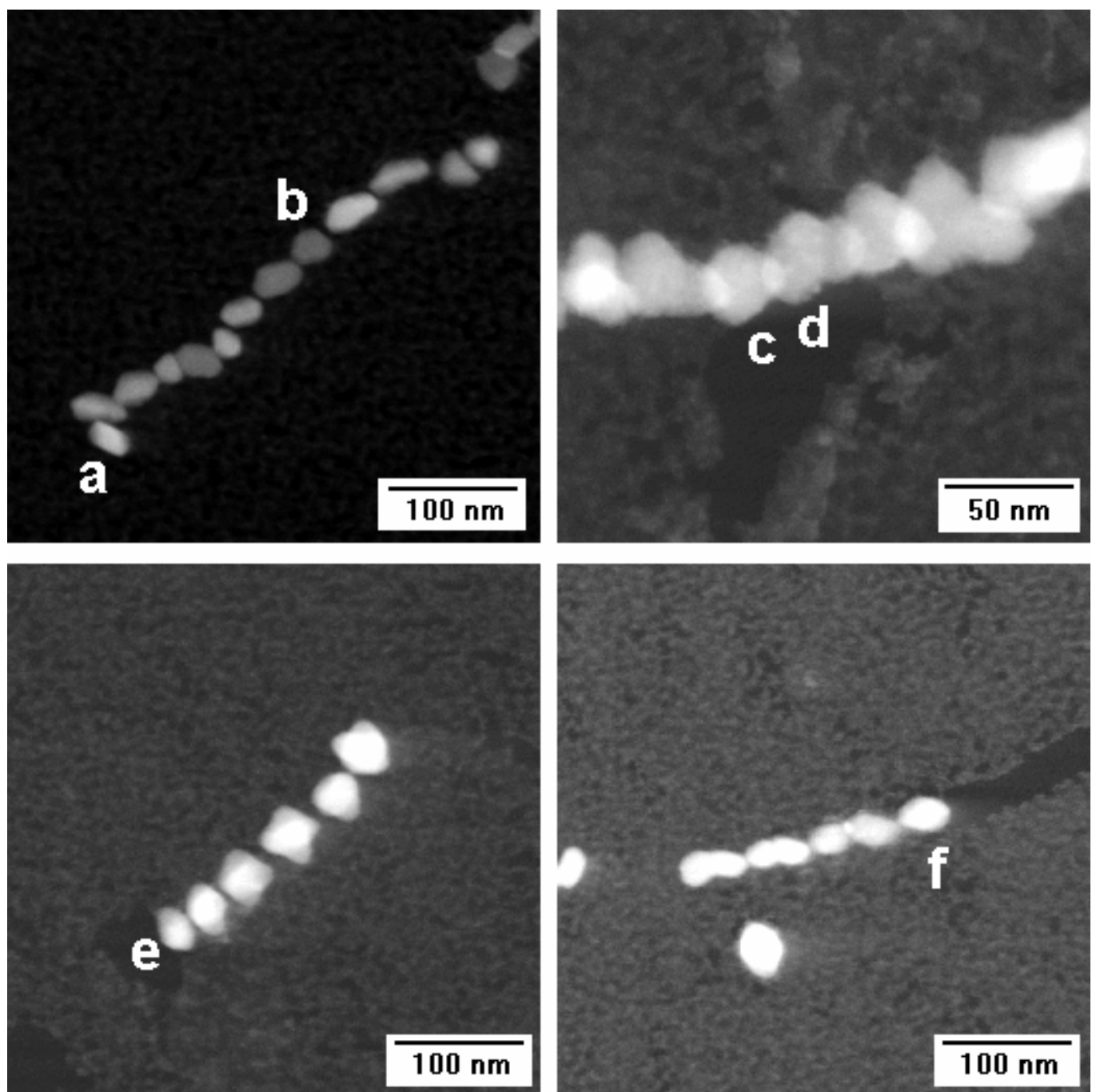

Fig 13

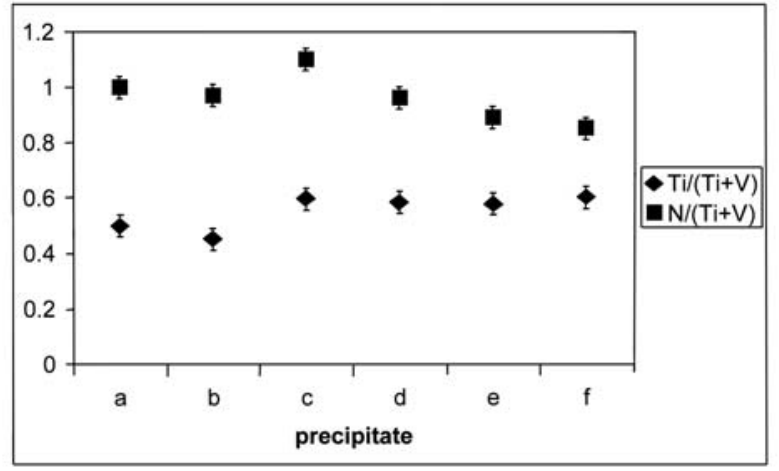

Fig 14 
